\title{
Amidst challenges, UK research hub moves closer to relocation
}

The UK government last month gave the green light for Europe's largest medical research center to be built in central London, bringing stateof-the-art basic biology and clinical research together under one roof. But the project still faces formidable challenges.

The new center will house the National Institute for Medical Research (NIMR), the biggest research body of the UK's Medical Research Council (MRC). For the past four years, officials and scientists have debated whether to move the NIMR to the heart of London from its current 47-acre site in the city's suburbs. Many researchers bitterly opposed an earlier proposal to relocate to a one-acre location, saying the tight space would mean staff cutbacks and limited facilities.

At 3.5 acres, the plot slated for the new center is considerably larger. But the NIMR will share the facility-to be named the UK

Centre for Medical Research and Innovationwith teams from Cancer Research UK and University College London. The $\$ 1$ billion center is scheduled to open in 2013 and will aim to accelerate translational research to turn laboratory advances into new therapies.

"The central London location-close to hospitals, universities and transport-will allow the UK to compete with other medical research developments worldwide and maintain a European lead," according to MRC chief executive Leszek Borysiewicz.

Scientists working at the center, located near the British Library and the busy King's Cross train station, will receive funding support from the Wellcome Trust, the fourth consortium partner.

"This unique opportunity provides the ability to put together a very large concentration of biomedical research scientists," says Paul Nurse, a British Nobel laureate, president of Rockefeller University in New York and head of scientific planning for the new research hub in London. "But clearly there are challenges."

Questions loom about how the four partners will collaborate, what steps will need to be taken to address community concerns and which research areas will take priority in the new space.

Looking ahead, consortium partners say the biggest challenge, given their different research agendas and histories, will be working together to develop an effective facility.

"The whole point is to have no barriers between scientific interactions," says Richard Treisman, director of Cancer Research UK's London Research Institute. "Obviously if you have four different funders involved, it's going to be an

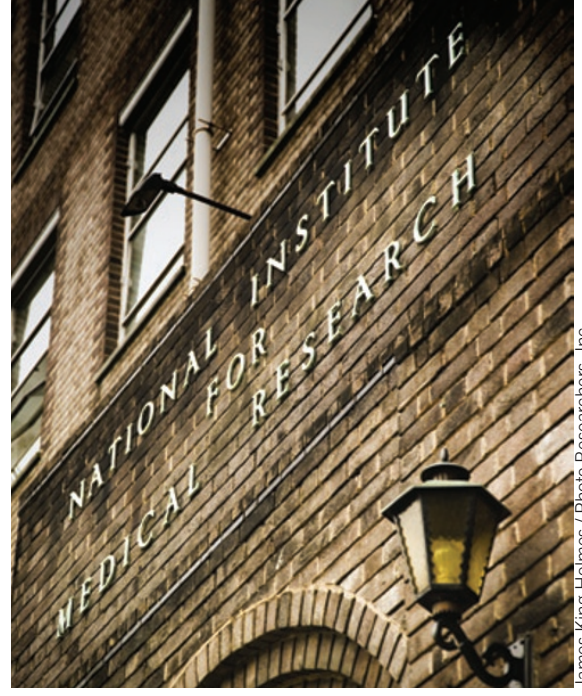

Opportunity knocks: The National Institute for Medical Research moves closer to relocation.

interesting challenge to make sure that you can realize the vision for the interactions on the shop floor."

A more immediate hurdle may be gaining local support for the project. The planned site of the new center sits within an area of land where the local government council has given provisional consent for developments such as community facilities or affordable housing. Plans for the new research center do not include either type of development. Additionally, residents worry that an accident might occur at the planned biosafety level 4 virus-containment laboratory-or that the large animal research lab might draw huge crowds of animal rights protesters. Consortium partners say that they will maintain a dialogue with the local community and that they remain confident the council will back the project.
The partners are already discussing the allocation of space in the new center, which will house up to 1,500 employees. Scientists have expressed concern that there will be insufficient space for researchers, support staff, equipment and lab animals, but Nurse says, "with appropriate design, it should be big enough."

The MRC and Cancer Research UK will shoulder most of the costs, and, according to Treisman, staff numbers will be determined by each partner's capital costs and revenue. "From our point of view, Cancer Research UK can support the move, so staff here are very positive," he says.

NIMR scientists are more apprehensive. Some estimates predict that moving to downtown London could increase operating costs by 30 percent, and they worry that might mean cuts to the NIMR's scientists and staff, who currently number 750 .

"We're looking forward to working with them to try and help design our future, but we are concerned about how the transition will be managed, especially if there has to be a reduction in the number of scientists," says Robin LovellBadge, head of the NIMR's department of developmental genetics.

The MRC emphasized that the new center is not a direct replacement for the NIMR, and the scientific direction the consortium decides on will in part determine which scientific areas are transferred. Nurse, who is now putting together the scientific planning committee that will set research priorities, says it is too early to say exactly what the new priorities will be.

Borysiewicz, meanwhile, stresses that the relocation is a move in the right direction: "Insufficient space is not a concern, getting the facilities to conduct world class research is."

Alisa Opar, New York

\section{NEW PUSH FOR EXPANDED ACCESS TO CHILD MEDS}

In a 10 December 2007 report, UNICEF, the UN children's agency, reported that 9.7 million children died in $\mathbf{2 0 0 6}$ before they reached their fifth birthday. A few days earlier, on 6 December, the World Health Organization launched a global campaign to boost research into medicines designed specifically for children, noting that drugs originally tested in adults do not always work the same way in youngsters.

*The category of Central and Eastern Europe and the Commonwealth of Independent States (CEE/CIS) includes countries such as Russia, Romania and Turkey.
Estimated deaths of children under the age of five in 2006

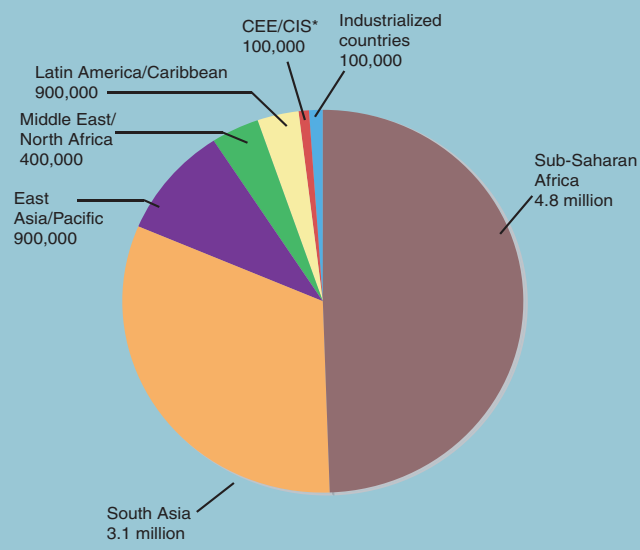

